\title{
O15 メソトレキセートが有効であった慢性ベリリウム肺の1例
}

○小清水直樹, 宮下晃一, 古河俊哉, 一條甲子郎, 勝又峰生, 西本幸司, 松浦 駿, 長岡深雪, 津久井賢 藤枝市立総合病院 呼吸器内科

【症例】50歳男性 【主訴】労作時呼吸困難

【既往歴】1978年白血球减少, 1985年B型肝炎ウィルスキャリアー 【現病歴】1984年からアルミニウム鋳造業などに勤務，1997年ま でベリリウム $(\mathrm{Be})$ の粉塵暴露あり。1995年会社検診にてびま 几性陰影を指摘され, 外科的肺生検を施行し, 慢性Be肺と診断 された. 徐々に労作時の呼吸困難が出現し, 2006年プレドニン (PSL) 20mgにて治療開始となった. PSL減量とともに呼吸困難 および陰影が増悪し, PSL増量にて改善するエピソードを繰り 返していた．2012年12月エンテカビル開始．2013年11月にも増 悪があり, PSLを12.5mgから30mgに増量されたが, 2014年2月 PSL15mgまで減量したところ, 再度増悪をみとめた. PSLのみ ではコントロール困難と考えられ，2014年4月患者の同意のもと にメソトレキセート（MTX）導入目的にて入院した。副作用は みられず，5月に退院した，投与 2 月後胸部CTにて，スリガラ
ス影, 浸潤影の改善をみとめ, KL-6も2400から1520に低下した. 肺活量, 肺拡散能は不変であった。

【考察】MTXは，サルコイドーシスの肺病変に対する有効例の報 告はあるが, 慢性Be肺への投与報告例は少ない, 有効な治療法 が少ない慢性Be肺に対しMTXが治療の選択肢となる可能性があ り, 文献的考察を加えて報告する.

\section{6 高熱とびまん性粒状影で発症したサルコイドーシスの一例}

\section{森谷梨加}

新潟市民病院

高熱と両側びまん性粒状影で発症し, 胸腔鏡下肺生検でサルコ イドーシスの診断に至った一例を経験した，症例は68歳男性で, 1週間持続する発熱で外来受診した．血液検査では肝胆道系酵素 の上昇, 炎症反応の上昇があり, 胸部CTでは両側びまん性に分 布し空洞を伴う多発結節影を認めた。 入院後の血液検查, 細菌培 養, BALF結果などからは診断に至らなかった. 肺生検組織診, 肝生検組織診で乾酪壊死を伴わない類上皮肉芽腫を認め, サルコ イドーシスと診断した．本症例のような空洞結節性病変を伴うサ ルコイドーシスは極めてまれであり，希少な例として報告する.

\section{7 胸痛と口渇を契機に診断されたサルコイドーシスの1例}

○種村 聡, 眞水麻以子, 石田卓士, 皆川真一, 川田 亮, 野崇幸一郎, 山岸格史, 古川俊貴, 太田求磨, 小林 理 新潟県立中央病院 内科

\section{【症例】25歳, 男性【主訴】胸痛, 口渇}

【病歴】右胸痛を主訴に近医を受診し，BHLを指摘されたため当 科へ紹介された。胸部CTにてBHLに加え，小粒状影を伴う斑状 影を認め, 心病変はみられなかったが, ぶどう膜炎と続発性緑内 障を認め, 血清ACE活性高值, BALF中のリンパ球増多とCD4/ CD8比の上昇, TBLBにて非乾酪性類上皮肉芽腫を認めたことか ら, サルコイドーシス (以下サ症) と診断した。問診にて2ヶ月 前から口渇を自覚していたことが判明. 下垂体MRI後葉のT1高 信号は消失しており, 高張食塩水負荷試験より中枢性尿崩症と診 断した，ステロイド治療は同意が得られず，デスモプレッシンの 補充療法にて経過観察中. 胸痛は自然軽快した.

【考察】サ症は多臟器に病変を来す疾患で, 罹患臓器に特異的な 症状がみられる一方で, 疼痛や疲れなどの非特異的な全身症状を 呈することがある。本症例は胸痛という非特異的全身症状を主訴
に受診し, 口渇という特異的臟器症状より下垂体病変が疑われた。 このようにサ症を疑った場合は, 詳細な問診により非特異的全身 症状以外の蔵器特異的症状を確認し, 症状より系統的に検索を進 めることが重要である. 